\title{
Joseph Shatzmiller \\ Church Articles: Pawns in the Hands of Jewish Moneylenders
}

For the most part, the pawns that were to be found in moneylenders' "shops" in the central and late Middle Ages were cheap objects, almost worthless. Poor borrowers had nothing better to offer. However, some rich institutions and opulent individuals presented creditors with spectacular and precious objects of art. Moneylenders dealing with church institutions accepted as sureties cult-articles considered sacred by Christians. The following pages will confront jurisprudence - religious and secular - on this aspect of the commerce of money with the reality of economic life in which these sacred articles played an important role.

\section{I.}

Not all Jews were strangers to the interiors of churches and to the beautiful ecclesiastical ornaments they preserved when they entered cathedrals or monasteries of the time. In England of the twelfth and thirteenth centuries, some Jews, perhaps even the majority, would leave their money and valuables for safekeeping in these churches. This was the reason for their frequent visits to the institutions of the rival religion. Quite understandably, some clergymen complained about this lively Jewish traffic in the Christian holy buildings. At a church council at Oxford in 1222, Stephen Langton, the most prominent ecclesiastical figure of his time, promoted a decree forbidding Jews such entrance, liberum ingressum et egressum. The prohibition was repeated in the diocesan statutes of Worcester in 1240 and of London from 1245-1259. In 1253, King Henry III issued royal legislation in this spirit ${ }^{1}$.

The late Professor Solomon Grayzel, master scholar of the relationship between the Church and the Jews in the Middle Ages, noticed the presence of Jews in these buildings of Christianity. He was of the opinion that the phenomenon was limited to England ${ }^{2}$. However, some of the Hebrew exempla, assembled around the year 1200 in the well-known "Sefer Hasidim", implied that things were not different in

\footnotetext{
1 Zephira Entin-Rokeah, The Jewish Church-Robbers and Host Desecrators of Norwich (ca. 1285), in: Revue des études juives 141 (1982) 331-362, in particular 333-334.

2 Cf. Salomon Grayzel, The Church and the Jews in the XIII't Century, revised edition (New York 1966) 35, note 75.
} 
the Rhineland of the time ${ }^{3}$. The pious authors of Germany hailed individuals who abstained from the practice. They gave the following illustration, "a Jew entered the court of a church. He heard a [Divine] voice (quoting 1Kings 14:9), 'And me, you cast away behind." 'To make up for the transgression, the Jew mortified himself for the rest of his life (Exemplum $\left.N^{\circ} 1357\right)$. Another exemplum involves the case of a man who entered the church and then regretted it. He turned to a Sage for instruction of penance. The Sage suggested, "every year on the day [on which you committed the transgression], you should mortify yourself." And, so he did ( $\left.{ }^{\circ} 1358\right)$. The Hasidim considered as realistic a situation in which a shrewd cleric indebted to a Jew took refuge in the church knowing that the creditor would not follow him ( $\left.\mathrm{N}^{\circ} 1362\right)$. They told also of a wonderful miracle that occurred during the funeral of a person who "made a point never to enter a church" ( $\left.\mathrm{N}^{\circ} 1356\right)$.

In twelfth century England, the relationship between Jews and churches was not limited simply to visitations or to safekeeping. Prelates, under financial pressure, would offer holy ornaments as sureties to Jews against loans they wished to obtain. Bishop Nigel of Ely (East Anglia), in conflict with King Stephen, was forced to pawn relics to Jews of Cambridge. This must have occurred around the year 1140 . A hagiographic source reported that among those relics was a golden crucifix belonging to King Edgar ${ }^{4}$. Some thirty years later, two Jews of Norwich, a father and son (Benedict and Deodatus, respectively), were sentenced to a considerable fine of twenty pounds for obtaining church vessels illegally as pawns ${ }^{5}$. Other English prelates involved in such transactions were Bishop Robert de Chesnay of Lincoln and Abbot William Waterville of Peterborough (active around 1155-1175). The abbot pledged, among other sacred relics, the arm of Saint Oswald ${ }^{6}$.

Similar practices crossed the channel and took place in the heart of Europe as well. It is quite possible that sacred objects, belonging to none other than the monastery of Cluny, fell into the hands of Jews. Peter the Venerable (1156-1192), its most famous abbot, expressed rage over the very fact of having to deal with the Jews ${ }^{7}$. A much calmer mood is detected in a letter he wrote to Henry of Blois, who became Bishop of Winchester; the great ecclesiastic thanked Henry for the financial support that helped retrieve sacred objects in Jewish possession ${ }^{8}$.

3 Jehuda Wistinetzki (ed.), Das Buch der Frommen (Sefer Hasidim, Hebrew) (Frankfurt a.M. 21924). Each of the exempla has a number in this edition. These will be given in the text of this essay between brackets.

4 Cf. H. P. Stokes, Studies in Anglo-Jewish History (Edinburgh 1913) 124.

5 Stokes, Studies ibid.

6 Cf. Joe Hillaby, The London Jewry: William I to John, in: Transactions of the Jewish Historical Society of England 33 (1992-1994) 1-44, in particular 9.

7 Jean Pierre Torrell, Les juifs dans l'œuvre de Pierre le vénérable, in: Cahiers de civilisation médiévale 30 (1987) 331-346.

8 Giles Constable (ed.), The Letters of Peter the Venerable, vol. I (Cambridge/Mass. 1967) 327330 , in particular 329. 
II.

Christian sensitivity about sacred vessels goes back a long time. As early as the end of the sixth century (August 591), Pope Gregory the Great chastised two clerics of Venafro in Campania for having sold to a "certain Hebrew" sacred articles from the treasure of the local church. These included "two chalices of silver, two crowns with dolphins, the lilies of other crowns, as well as six palliums - great and small". The Jews, orders the Pope, should restore all they got; penance should be imposed on the clerics9. More than two hundred years later, in August 806, in a Carolingian capitulary, the clergy of the highest level were urged to prevent that "anything of the gems or the vessels or other ecclesiastical treasures should be sold to Jews". It further stated, "we have been told that Jewish merchants... boast that they are able to buy... whatever they like"10. Another capitulary, this time of suspected authenticity, menaced such Jews that "their right hands shall be cut off"11.

In the twelfth and thirteenth centuries, when credit operations spread or intensified and became widespread, the attention moved from merchants and their acts of purchasing to moneylenders and the pawns and sureties they were holding. Pope Alexander IV (1254-1261) was one of many who expressed ire about it in these centuries. In a bull ("Bulla") issued on August 23, 1258, he urged the clergy to show reverence to "the vestment of their ministry, the sacred ornaments, the chalices and the ecclesiastical vessels". "We heard, and we speak of it not without bitterness of heart, that some clergy make no distinction between the sacred and the profane, and they dare leave such vestments, ornaments and vessels as loan pledges with the Jews." Here, the Pope's concern reached its highest point: "And these very Jews, like ingrate enemies of the cross and the Christian faith, treated these pledges with irreverence to the disgrace of the Christian religion. And [these Jews] acted so nefariously towards them as it is shameful to speak and horrible to hear."12

More than a hundred years earlier, Peter the Venerable had the following to say about the blasphemous treatment to which sacred objects were subjected: "Christ, through the otherwise insensible vessels consecrated to him, suffers directly the Jewish insults since, as I have often heard from truthful men... they direct such wickedness against celestial vessels as is horrifying to think and detestable to say." The venerable abbot goes on, "The sacred vessels held captive among them... as in olden times among Chaldeans, suffer shame even though they are inanimate. Indeed, Christ felt the Jewish abuse in these insensate vessels sacred to him."13

Rigord, the biographer of Philip Augustus of France, in his "Gesta", written and rewritten in the years 1196 and 1207-1208, was a bit more open writing about these

9 Cf. Amnon Linder, The Jews in the Legal Sources of the Early Middle Ages (Detroit, Jerusalem 1997) 420-421.

10 Linder, The Jews 344.

11 Linder, The Jews 345 and note 324 there.

12 Cf. Grayzel, The Church (as in note 21 infra) 62-64.

13 Cf. Robert Chazan, Medieval Stereotypes and Modern Antisemitism (Berkeley 1997) 51. 
"abuses": the biographer tells us that Phillip expelled the Jews in 1182 from his domain because of the "culmination of their wickedness". His explanation: "Certain ecclesiastical vessels consecrated to God, the chalices and crosses of gold and silver bearing the image of our Lord Jesus Christ crucified had been pledged to the Jews by the way of security... these they used so vilely in their impiety and scorn of the Christian religion that, from the cups in which the body and blood of our Lord Jesus Christ was consecrated, they gave their children cakes soaked in wine."14

With such allegations circulating in society, there was little wonder that, for some, the alleged nefarious behavior of the Jews amounted to what Professor Ivan Marcus labeled rightly "latrine blasphemy"15. The above-mentioned Rigord believed this was true. He knew of "a certain Jew" who held certain ecclesiastical objects as pledges. "He had a gold cross marked with gems, a book of the Gospels decorated with gold and precious stones in an extraordinary manner, silver cups and other vessels. He placed them all in a sack and vilely threw it into the deep pit which he used to relieve himself."16 A hagiographic treatise, "The Miracles of Notre Dame", a collection of miracle stories, accompanied in some manuscripts by illuminations, relates the terrible story of the Jew of Constantinopolis who threw the icon of the virgin to the gutters. It had been saved, cleansed, and performed miracles. Christians could learn of it not only from books but also from observing church windows ${ }^{17}$.

Ecclesiastical jurisprudence took seriously the account of such horror stories. In their assemblies, prelates made recourse to no uncertain prohibitive terminology when trying to change the course of events. Thus, the decree of a synod held by Odo of Sully, bishop of Paris (1197-1208), stated that "no cleric... shall... in any manner pledge to a Jew the books or the ornaments of a church"18. In Trier, in 1227, a somewhat more mitigated legislation was agreed upon: “The clergy shall never let out of their possession any of the church ornaments, nor shall they dare to give up to Jews any religious articles without special permission from us." 19 Two years later, in England, a regulation of the bishop of Worcester forbade Jews to receive ecclesiastical books, vestments or other ornaments as pledges or for any other reason. The bishop threatened to cut such Jews from any social intercourse with Christians ${ }^{20}$. Other thirteenth century assemblies employed similar rhetoric. In 1255, the diocesan synod of Valencia wanted things to be clear: "No cleric should

14 Cf. Jacob Rader Marcus, The Jew in the Medieval World, A Source Book: 315-1791 (revised edition by Marc Saperstein, Cincinnati 1999) 27-30, in particular 29.

15 Ivan G. Marcus, A Jewish-Christian Symbiosis: The Culture of Early Ashkenaz, in: David Biale (ed.), Cultures of the Jews: A New History (New York 2002) 449-516.

16 Ivan G. Marcus, A Jewish-Christian Symbiosis 480.

17 Alexandre Laborde, Les miracles de Notre Dame, compilés par Jehan Miélot (Paris 1929) 102 and plate $\mathrm{N}^{\circ}$ xi. cf. also to Ivan G. Marcus, (as in note 16 above) 481 .

18 See Grayzel, (as in note 2 above) 300-301.

19 Grayzel, The Church 318-319.

20 Grayzel, The Church 320-321. 
pledge [to a Jew] a chalice, vestments, covers of altars or books." 21 The commerce in "sacred objects" was a major concern of assemblies like that of Meaux in 1287 or that convened the same year by Jacob, Archbishop of Gniezno ${ }^{22}$.

III.

For their part, Jews were aware of the rage these transactions aroused in society they were also attentive to the danger which some of these moneylenders may have had to face. A rabbinic synod, convoked by Rabbi Jacob Tam (c. 1100-1175) around the mid twelfth century, tried to amend this state of affairs. In the decree issued by that synod, Jews were warned "not to accept church vessels as security for debt". "Not to buy the chalice or the cross or holy vestments or prayer books of a church or its vessels." And again, "Not to buy a stolen chalice or a cross or holy vestments or prayer books of a church or any of its vessels". The reason: "Because of the peril." The injunctions went further, warning the Jews "not to buy stolen things such as images or a chalice or priestly vestments and prayer books or vessels of worship" and again: "Because of the danger" 23 . A pupil of Rabbi Tam, Eliezer of Metz (c. 1115-1198), repeated his teacher's interdiction in his own "sefer yere'im” (“Book of the God fearing” Responsum N³64) ${ }^{24}$.

The moralists of "Sefer Hasidim" writing at the same time also contributed to this campaign of dissuasion ${ }^{25}$. Their exempla, to be sure, did not have the power of law, yet they hoped to influence - even to frighten - their audience by indicating practices one should avoid. A general observation is found in exemplum $\mathrm{N}^{\circ} 1349$ according to which "Most people who dealt with priests did not keep their wealth down to the end of their lives". The reason? "Because they provided them [the priests] with articles to [practice] their idolatry." An exemplary behavior was displayed on the other hand, in the case of a Jew, "who lent on pledges [like] crosses and other objects". Upon his demise, one of his coreligionists, who knew where the objects were stored, refused to divulge the whereabouts to the heirs, "If I shall tell it... they shall go ahead and sell them to priests and monks." Being closedlipped, thus the Jew avoided committing a sin ( $\left.\mathrm{N}^{\circ} 1349\right)$. The authors related in another story ( $\left.\mathrm{N}^{\circ} 1359\right)$ an example of a Jew who did not refrain from selling orna-

21 Salomon Grayzel, The Church and the Jews in the XIII Century, vol.II, ed. Kenneth R. Stow (New York, Detroit 1989) 276.

22 Grayzel, The Church 280-281.

${ }^{23}$ For the three first quotations, cf. Lowis Finkelstein, Jewish Self-Government in the Middle Ages (New York ${ }^{2} 1964$ ). The first is to be found on page 201. Finkelstein's rendering of these paragraphs into English has the character of an interpretation rather than a close translation. The Hebrew original employs much more coarse language, cf. 178-195 and 211.

${ }^{24}$ I have not seen the original of "sefer yere'im" and count on information provided in: Jewish texts on the visual arts, edited with commentary by Vivian B. Mann; Rabbinic texts translated by Eliezer Diamond (Cambridge/U.K., New York 2000) 13 and 176 note 50.

${ }^{25}$ Cf. note 3 above. 
ments to priests who embellished with them their places of worship. He was punished by Heaven on the day of his death.

These synodal decrees and moralistic warnings might have had some impact in the world of business. The following three examples may have lead to such a conclusion. In thirteenth century England, two church robbers, who were unable to dispose of their booty, claimed that "no Jew wants to receive them or to lend money against them". ${ }^{26}$ A similar deadlock occurred in Zurich in 1272 or 1273: No Jew of the city would touch a chalice worth no less than seventy marks ${ }^{27}$. Abstention from such deals was mentioned in a short, yet precious, Hebrew document kept today in the Archives of Bern, Switzerland. There, an unknown Jew wrote a memorandum to himself noting the issues he may raise when negotiating a charter of privileges for himself. He should, among other benefits, be allowed to receive all sorts of pledges and pawns, with the exception of church vessels. He adds, "Because of the danger". Clearly, we have here an echo of the decrees and injunctions of the 1150 rabbinic assembly ${ }^{28}$.

The bark of these decrees - Christian or Jewish - seemed, however, to have been more menacing than their bite. Jews and Christians found ways to circumvent - or ignore - them in the centuries that followed. As far as the Jews were concerned, they could count on the fact that not all rabbis followed the teaching of "Sefer Hasidim" or shared the fears of Rabbi Tam and his followers. The authority of the legendary founder of rabbinic studies in Western Europe, R. Gershom of Mainz, "The Light of the Diaspora" (ca. 960-1028), who saw nothing wrong in dealing with priestly vestments or any other church articles, would lend them a free hand. The great man's reasoning taught them "Gentiles [of our time] are not idolaters" 29 . This axiom was embraced by a plethora of followers.

R. Eliezer ben Nathan of Mainz (c. 1110-1190), known by the acronym "Ravan", a contemporary of Jacob Tam and a friend of his, advocated also a more permissive way of doing business. With the exception of incense ("levonah" in Hebrew) that serves in the church, almost any other articles should be exempted from interdiction. The Gentiles of his day - so goes his argument - were far from being inveterate idolaters. At times, they did not care about their holy days and went ahead with their work. Some did not attend church regularly. To the extent they did, it was simply due to the fact that they followed the ways of their ancestors, and because they enjoyed the surroundings. A Jew was allowed to sell priests' clerical vestments and coats ("Dossals"), as they served their personal use

26 Cf. Zefira Entin Rokéah, Crime and Jews in the Late Thirteenth Century England: Some Cases and Comments, in: Hebrew Union College Annual 55 (1984) 135-136, note 132.

27 Cf. Gerd Mentgen, Studien zur Geschichte der Juden im mittelalterlichen Elsaß (Hannover 1995) 441.

28 This short and precious document was published by Ben-Zion Dinur in his multi-volume Israel in Diaspora (Hebrew). The original is preserved at the archives of the city of Bern (Switzerland). Cf. Dinur, op. cit., vol. B (1) (Tel Aviv 1965) 278-279.

29 Shlomo Eidelberg (ed.), The Responsa of Rabbenu Gershom Meor Hagolah (Hebrew) (New York 1955) 75-77 Responsum $\mathrm{N}^{\circ} 21$. 
only and did not cover any of their sacred objects. "The same way it is permitted to sell them [such objects], it is allowed to extend loans on the security of church vessels and of Dossals, for the reasons I have mentioned." The distinguished Sage continued, "Also, one can extend loans on the security of church vessels because they are there [only] for the priest to drink from them when praying." Apparently, Eliezer ben Nathan believed in these distortions of ecclesiastical practices. His tolerant attitude was not all encompassing. "It is forbidden to extend loans on security of their statues, icons and censer bearers", insisted the Mainz Rabbi ${ }^{30}$.

The analysis, developed a generation later by Isaac b. Samuel of Dampierre followed essentially the same path. Isaac, known also as "The $\mathrm{Ri}$ ”, a nephew of Jacob Tam, replaced his uncle as head of the rabbinic academy of Champagne. He was considered the supreme authority of his time. A contemporary of the authors of "Sefer Hasidim" and a sympathizer of their mystical teaching, Isaac did not follow their lead in what concerned pawns and pledges. At the origin of his thinking was the distinction between what was essential for Christian worship and what was nothing more than paraphernalia for the personal use of the priests. Accordingly, to quote some of the examples he raised, Jews may do business with the rest of wax candles that were put away by priests and also with wax not intended to be used in the church. Loaves of bread were also legitimate objects of commerce as the Christian folk brought them to their holy places not as sacrifice to their deity but rather for the use of the church's personnel. Priestly vestments had nothing sacred inherent in them. They served just as ornament ("noy" in Hebrew, that is elegance) and should not be considered in the context of worshipping idolatry. The analysis applied also to vessels he called "chalice”. It was his understanding that these vessels did not make up part of the Christian cult. Attention should be paid, nevertheless, regarding censer bearers of incense. R. Eliezer ben Nathan, too, maintained that they should be out of bounds for Jewish moneylenders ${ }^{31}$.

\section{IV.}

Whether such lenient rulings encouraged Jews to lend against church objects or just condoned existing practices is not clear from the Hebrew sources. Archival documents, on the other hand, show that this kind of exchange was in full vigor in the high and late Middle Ages, and that Christians, no less than Jews, lent a deaf ear to restrictive legislation. In this respect, Italian data, revealed in recent years

30 Cf. Eliezer bar Nathan, Sefer Ravan which is the book of Even ha-Ezer (Hebrew) (Jerusalem 1984) Responsa Nos 288-289.

31 See Isaac's commentary to the tract “Idolatry” (“Aavodah Zarah") of the Babylonian Talmud, fol. 516. On him see E. E. Urbach, The Tosaphists: Their History, Writings, and Methods (Hebrew) (Jerusalem 1980) I:226-260, and J. Fauer, The Legal Thinking of the Tossafot, an Historical Approach, in: Dine Israel 6 (1975) XLIII-LXII, in particular LXVIII. 
from the regions of Umbria by Professor Ariel Toaff, is very important. The following are just some of the findings ${ }^{32}$. The humble Umbrian canons of the Church of Santa Maria de la Pieve, some time in the year 1304, gave away an embossed silver chalice to Jews Cascia (Toaff $\mathrm{N}^{\circ} 50$ and $\mathrm{N}^{\circ} 120$ ). Almost one hundred years later, in November 1386, a gold frieze, embroidered with pictures of saints, formed a crucial part of a monetary transaction ( $\left.\mathrm{N}^{\circ} 477\right)$. In March 1385, a long list of articles was recorded for a complicated transaction, with a significant amount of money was at stake. The borrower was the municipality of Assisi, the famous Umbrian town in central Italy. Its governing council approached the Jew, Anselmo, for a loan of one thousand two hundred gold Florins. The council persuaded the Church of St. Francis to lend them a collection of sacred articles that they handed over to Anselmo. The list included twenty-one items, most of them silver objects. The total weight of the objects was over sixty pounds. Included as well was a chalice made of gold that weighed close to four pounds and two statues of the virgin, one of which weighed more than five pounds. Also included were two censers ("Thuribules") one large and one small, a pedestal for a standing cross as well as four candelabras of silver. To the golden chalice mentioned above, six others made of silver were added. Embroidery was also present in the inventory: one piece that served as a cover to Mary's altar was decorated with pearls. Another two tapestries used golden thread, one in the form of a griffin. A priest's gown of red cloth was ornated on both sides with pearls in the form of the cross. Most astounding was an object that belonged to Pope Nicholas IV (1288-1292), a cape intended for wet weather that had been decorated with pearls $\mathrm{s}^{33}$. Given the value of these treasures, the Church of St. Francis insisted that its loan be limited in time to two months and no more. A similar, yet even more complicated, arrangement was concluded in November 1435 in Bologna, the capital of the region of Emilia Romagna. The Jew, Habraam di Datilo, asked for securities for a loan of one thousand pounds, an enormous sum of money. The commune of the city appealed to no less than thirty-one religious institutions for help. Twenty-one of these were churches, five were monasteries, two were hospitals, and three may have been monasteries as well. Most institutions gave one article, although four churches and one monastery contributed two each. The list of the thirty-eight objects that were assembled this way included six chalices, fifteen chasubles, two copes, two covers of altars, four missals, seven antiphonaries and three priestly garments ${ }^{34}$. Other Umbrian communes that used the services of Jewish moneylenders were those of Todi and Spoleto. The first of the two appeared in the documentation in a different light than that of Assisi or Bologna: on

32 Ariel Toaff, The Jews in Umbria, 3 vols. (Leyden 1993-1994). Professor Toaff calendared many of his documents and gave numbers to all of them. In what follows I shall refer to these numbers.

33 Ariel Toaff, The Jews in Medieval Assisi 1305-1487: A Social and Economic History of a Small Jewish Community in Italy (Firenze 1979) 139-141.

${ }_{34}$ Cf. Ludovico Frati, La vita private di Bologna dal secolo XIII al XVII con appendice di documenti inediti (Bologna 1986) 240-241. 
June 13, 1368 it purchased a chalice (probably redeemed) from the Jew, Guillelmo. The sum involved was just four florin and thirty-five shillings (Toaff, $N^{\circ} 232$ ). In the midst of war in 1414, Spoleto was pressed for financial liquidity. In August, the rector of the city could see no other way but to hand part of his private silverware to a Jewish moneylender in order to secure a loan of one hundred and fifty Florins $\left(\mathrm{N}^{\circ} 730\right)$.

Having sacred Christian objects in their possession was a phenomenon that, in all probability, was not limited to central Italy where systematic research has been carried out in recent years. Another region that benefited from scholarly attention was that of Campania, or more precisely the Aragonese court of Naples. Jews, among other creditors, had access to all kinds of luxurious items. One of them, Isach di Salam da Campobasso, was recorded in an inventory listed on January 1, 1470 as possessing a golden cross that had seven pearls, two diamonds and eight rubies attached to $\mathrm{it}^{35}$. In the city of Oberehnheim, in Alsace (another region thoroughly studied), a Jew had in his possession a gilded cross, while a coreligionist, from Rosheim, received a chalice as surety. Both were dealing with the Abbey of St. Leonard" ${ }^{36}$. For the "transit region" of Savoy-Piemont, a document of the year 1404 stated that Josson Aaron, a Jew of Chambéry, had in his possession a gilded reliquary profusely adorned with small bells ${ }^{37}$.

\section{V.}

It would be wrong to conclude from the Italian evidence that Christian sensitivity had been abolished altogether and that conciliar decrees were completely forsaken. While many, perhaps most, Christians did not follow these injunctions; their authority did not fade away without leaving any trace. A letter by Pope Urban V, sent in December 1370 to the Archbishop of Rossano in Calabria, can testify to that effect. It had to do with the misbehavior of a monastic superior ("archimandrite") by the name of Dorsiosus. The avalanche of accusations listed by the papal chancery of Avignon included the allegation that he pawned to "a certain Jew", against a usurious loan, chalices, silver crosses and other ecclesial ornaments that belonged to the Monastery of St. Maria in Patire ${ }^{38}$. Notice should be paid to the fact that these lines were written close in time to the exchange that took place in Assisi, as mentioned above. The Spoleto transaction of 1414 saved the uninitiated from another possible pitfall, namely from the illusion that Jews got access to luxurious

\footnotetext{
35 Cf. Filena Patroni Griffi, Banchieri et gioielli alla corte aragonese di Napoli (Napoli 1992) 21.

36 Cf. Gerd Mentgen, Elsaß (as in note 27 above) 39.

37 Cf. Thomas Bardelle, Juden in einem Transit- und Brückenland. Studien zur Geschichte der Juden in Savoyen-Piemont bis zum Ende der Herrschaft Amadeus VIII. (Hannover 1992) 185186.

38 Cf. Shlomo Simosobn, The Apostolic See and the Jews; Addenda, Corrigenda, Bibliography and Indexes (Toronto 1991) 11-13, Appendix $N^{\circ} 13$.
} 
objects solely when dealing with ecclesiastics. The Rector of Spoleto was not the only secular figure who exposed Jewish moneylenders to the sumptuous and the elegant. Other individuals and institutions, not related to the church, made similar transactions. Their history, however, must be dealt with in a separate communication. 